Journal of Teacher Education for Sustainability, vol. 19, no. 2, pp. 121-137, 2017

\title{
Teacher Education for Sustainability: The Awareness and Responsibility for Sustainability Problems
}

\author{
Dunja Anđić and Sanja Tatalović Vorkapić \\ University of Rijeka, Republic of Croatia
}

\begin{abstract}
The theoretical framework of the present research is based on the socio-psychological model of sustainable behaviour by Juárez-Nájera (2010). For the purposes of this paper, just part of the research is related to personal norms. The paper provides the results of the awareness of consequences and the attribution of responsibility for environmental/ sustainability problems among students of the four Faculties of Teacher Education in four countries, Bosnia and Herzegovina, Croatia, Slovenia, and Serbia. Research results indicate that students from Croatian and Slovenian Faculties of Teacher Education are characterised by a more pronounced awareness of environmental/sustainability problems than the students from Bosnia and Herzegovina and Serbia. The responsibility for environmental/sustainability problems is higher among the students of the Faculty of Teacher Education from Croatia and Serbia than among students from Bosnia and Herzegovina and Slovenia. It seems that a country is the major determiner of awareness and responsibility for environmental/sustainability problems. In general, the results of the present research provide significant guidelines for the reflection on the future of initial teacher education for sustainability and need for conducting interdisciplinary and cross-cultural research on personal norms and sustainable behaviour.
\end{abstract}

Keywords: awareness, education for sustainable development, responsibility, sustainable behaviour, university students of initial teacher education

\section{Introduction}

The scope of Sustainable Development (SD) is constantly intensifying and is being analysed through an interdisciplinary approach. Since the development of a number of approaches to transformation and implementation of SD is not possible without education, a change towards the environmental and sustainable behaviour (SB) is also not possible if the current behaviour is not changed through systematic education (Huckle, 2006). Teachers, as holders of interdisciplinary education, play a key role in this process. According to Besong and Holand (2015, p. 5), "the purpose of integrating sustainability in higher education programmes is to enable students to improve the quality of life on this planet while building fair, equitable and just futures for all. To effectively do this, the knowledge, skills and dispositions of higher education students need to be re-oriented 
towards sustainability." Framing interdisciplinary curriculum in a way that connects and develops various domains of learning encourages the development of those factors that affect the formation of SB, in particular, the behaviour of the future teachers - students, whose role is essential in the education for sustainability for future generations and sustainable citizens of a global society. The students are often a mirror of their teachers; hence, values, attitudes and behaviour of teachers are often reflected trough their students.

According to the available literature, there is no universally accepted definition of the terms "pro-environmental behaviour", "environmental behaviour" or "sustainable behaviour". Different definitions of these concepts may be found in numerous studies (Kollmuss and Agyeman, 2002; Steg and De Groot, 2010; Stern, Dietz, Abel, Guagnano, and Kalof, 1999). One possible demarcation of pro-environmental and environmental behaviour is based on the following: environmental behaviours are intentional behaviours that affect the environment, while pro-environmental behaviours are protective behaviours that affect the state of the environment, i.e., they are forms of socially desirable environmental behaviour (Krajhanzl, 2010, p. 252). ${ }^{1}$ The concept of SB is related to the afore-mentioned concepts and has developed from previous theories and models of pro-environmental and environmental behaviour. In accordance with these considerations, the present paper is based on the following definition: "SB is a set of effective, intentional, and expected actions for the purpose of accepting responsibility for the prevention, preservation, and protection of natural and cultural resources, including the integrity of animal and plant species, as well as the individual and social well-being and financial security of current and future generations" (Juárez-Nájera, 2010, p. 56). Since the present research was based on the socio-psychological model of SB by JuárezNájera (2010), the authors have also accepted this definition because it describes both the behaviour and the model itself.

Many authors associate the interpretation of environmental, pro-environmental, and SB with social factors as possible predictors, and they place an emphasis on the psychosocial interpretation of these behaviours. Such explanations are in accordance with the modern notion that environmental problems are becoming part of a wider problem of people's attitudes towards the environment. They are socially conditioned; therefore, their causes are found in the approaches that are based on external factors rather than internal, i.e., they are found in environmental factors such as demographics and geography, economics, politics, education, and culture.

\section{Theoretical Framework of the Research}

The theoretical model, which forms the foundation of this cross-cultural research, was taken over from Juárez-Nájera (2010), who included in the construction of the socalled socio-psychological model of SB some of the key theories that focused on questions of the causes, impacts, predications, and manifestations of ecological/pro-ecological behaviours. The theoretical model/socio-psychological model of SB by Juárez-Nájera (2010) contains operational definitions of the four fundamental dimensions of SB: universal human values, consciousness of ecological problems, responsibility for environmental problems, and inter- and intra-intellectual personal intelligence (see Anđić and Tatalović Vorkapić, 2014, 2015). The author based the first scale on the "Questionnaire on SB", which she constructed to measure SB based on the universal values of Schwartz (1977). 
The second and third scales are based on Schwartz's norm activation theory and its modification by Stern et al. (1999), the norm activation model, and the fourth scale is based on connecting emotional intelligence by Boyatzis \& Sala (2004) and Gardner's theory of multiple intelligences (1983). The focus of the present research, for the sake of practicality and scope of all results, is on the second and third scale relating to the area of personal norms. Attitudes (reflecting individual specific beliefs about behaviour) and external factors affect the intentions, and as such represent key components in the formation of behaviour (Anđić and Tatalović Vorkapić, 2015). The backbone of the research is Schwartz's norm activation theory (NAT, 1970), also known as the norm activation model (NAM, Schwartz, 1977; Schwartz and Howard, 1981, modified by Stern et al., 1999). The central element of the norm activation theory refers to personal norms. Intention is defined as a key factor that encourages pro-social behaviour. Within Schwartz's NAT theory, and later NAM models, four situational activators of personal norms stand out (awareness of a need or a problem, situational responsibility for a need or attribution of responsibility for negative consequences of inaction, efficiency as an identification of actions for detecting the needs of others or other people's values, the ability to facilitate relief) and two activators at the level of personality traits (awareness of consequences and denial of responsibility). Two conditions are necessary for the activation of personal norms: awareness of consequences and acceptance of personal responsibility (Stern et al., 1999). The core of the NAT theory is based on a complex model and the relationship in the decision-making process in a variety of moral situations. NAM explains pro-environmental behaviour as a product of personal norms whereby pro-environmental behaviour is considered to be pro-social behaviour. In 1999, Stern incorporated it into the VBN theory, i.e., the value-belief-norm theory. Stern also included Schwartz's theory of environmental value $(1973,1978)$ within the VBN theory and the so-called NEP scale, better known as the New Environmental Paradigm. The NEP scale (Dunlap and Van Liere, 1978) originally comprised 12 items grouped into three categories that referred to the balance of the environment, limiting the growth and people's power over nature, but it was later modified due to criticism (it was revised by Dunlop et al., 2000) (Anđić and Tatalović Vorkapić, 2014). Other authors have dealt with the development of this theory and models: Guagnano, Schwartz and Howard (1981, 1982); Heberlein (1972); Stern and Dietz (1995, 1998); Stern, Dietz and Kaloff (1993); Stern et al. (2000) (Blamey, 1998). This model, as well as its upgrade in the form of a sociopsychological model of SB by Juárez-Nájera (2010), was the basis for the implementation of detailed research. In the present paper, the authors provide only partial results of the research.

\section{Literature Review}

Based on current literature, research on pro-ecological/SB has focused on the research/ testing of various internal and/or external factors. For example, gender and sex (Stern, Dietz, and Karloff, 1999; Zelezny, Chua, and Aldrich, 2000, etc.), socioeconomic conditions (Davey, 2012), educational content, level (Scott and Willits, 1994) and length (Kollmuss and Agyeman, 2002, p. 248), age and level (Davey, 2012, p. 27).

Studies on geographical locations and cultural characteristics (Kelly, Kennedy, Faughnan, and Tovey, 2004) show that there is a clear division among environmental 
values, attitudes, and behavior in European countries (Kelly et al., 2004, p. 14). Those studies focused on countries belonging to different geographical, cultural, and sociopolitical regions of Europe, and differences were expected. Schultz, Gouveia, Cameron, Tankha, Schmuck, and Franek (2005) conducted research on six continents, analysing the geographical context. The research results confirmed the cross-cultural generality in four (out of six) samples used in the research: values of personal abstinence (according to Schwartz). Ecological behaviour was moderated from the awareness of the consequences and attributing responsibility for the perception of global ecological problems, however, not for local problems in the context of the value of personal gain and ecological behaviour. Milfont, Sibley, and Duckitt (2010) extended the research (by Schultz et al. from 2005 ) in 50 countries and confirmed the cross-cultural applicability of the theory of moral-norms activation among cultural groups of respondents.

The importance of the role of institutions can also be significant because "if the role of colleges and universities is to educate members of the society, then they must be an active instrument of sustainable movement" (Beringer, Malone, and Wright, 2006, p. 1). Molina, Fernandez-Sainz and Izaguirre-Olaizola (2013, p. 13) proved in their research conducted at four universities that formal education and knowledge of environmental problems clearly affected pro-environmental behavior, but in a very complex way. Objective and subjective knowledge affect the environmental performance of students from highly developed and developing countries, while the level of education, i.e., the type of qualification is significant only in developed countries.

\section{Context of the Study}

The present research dealt with the Faculties of Teacher Education in countries that occupy the same geographic area - better known as the territory of the former Yugoslavia, i.e., the region of Southeast Europe/Western Balkans. Each country considered within the framework of the research has found itself at different levels of the transition processes embedded in the democratization of the society. In cultural terms, this area is defined by very similar linguistic expressions. Education systems in these countries are very similar. In higher education institutions, there are also similarities in settings. Departments are autonomous units that operate within the faculties and offer study programs for preschool or elementary school education and their curricula are in line with the curriculum of other faculties responsible for teacher education. The analysis of study programmes/curricula for preschool teacher/elementary school education has been found to have common characteristics: all four faculties have programmes/curricula aligned with the Bologna process. Teacher education models include the undergraduate and graduate university level, and professional levels. It is important to note that during the implementation of the research, the Republic of Slovenia was the only member of the European Union (since 2004). The Republic of Croatia was in the process of meeting the conditions for the European Union membership. Serbia and Bosnia and Herzegovina are not yet its members, though they are trying to initiate the accession process. The described context is related to the selection of faculties, i.e., the sample of students who participated in the research. The reasons for the choice or selection of faculties for participation in the research included geographic affiliation to the region or countries in the region, socio-cultural and political contexts related to language and script, nation- 
ality of students and EU membership, similarity of study programmes, and accessibility to the institution.

Therefore, the basis of research hypotheses was that there would be no differences among our respondents. However in the present research, the authors did not refer to a representative sample for all faculties or for the entire country but to the students of four Faculties of Teacher Education in these four countries. The differences would not be present either in the level of responsibility or awareness. The authors started from the assumption that education could be a predictor of SB if it systematically encouraged value changes, attitudes, personal norms, sense of responsibility, intelligence, and other (Anđić and Tatalović Vorkapić, 2014, p. 81). Referring to the students of the Faculties of Teacher Education, who are one of the holders of education in their countries, it was expected that their results would be significantly above the mean value. The mentioned viewpoint opens up the way for many opportunities in the construction of interdisciplinary programmes/courses for teacher education based on psychological, social or educational premises that are "changing" past behaviour.

\section{Methodology}

\section{Aim, Tasks, and Hypotheses of the Research}

The aim of the research was to measure the awareness of environmental problems and responsibility for environmental problems/sustainability among the students from four Faculties of Teacher Education in the four different countries (Bosnia and Herzegovina, Croatia, Slovenia, and Serbia).

To reach the aim, the following tasks were set:

a) to measure the awareness of environmental/sustainability problems among university students from four faculties of teacher education;

b) to measure the responsibility for environmental/sustainability problems among university students from four faculties of teacher education;

c) to perform the correlation analysis between the awareness and responsibility for environmental/sustainability problems and socio-demographic variables (age, study year, study programs); and

d) to test the significance of differences in the awareness and responsibility for environmental/sustainability problems among university students from four faculties of teacher education.

Given the extremely small number of research on this subject ${ }^{2}$ in terms of testing the difference in awareness of and responsibility for environmental/sustainability problems, the following hypotheses were set:

H1) the value of the awareness of environmental/sustainability problems is expected to be above the mean value on the measuring scale among the group of university students ${ }^{3}$;

$\mathrm{H} 2$ ) the value of the responsibility for environmental/sustainability problems is expected to be above the mean value on the measuring scale among the group of university students;

H3) a significant positive correlation is expected to be found between age and course attendance with awareness and responsibility for environmental/ sustainability problems regardless of the country; 
H4) significant differences are not expected in the awareness and responsibility for environmental/sustainability problems among the group of university students.

\section{Participants}

In the research, a convenient sample of students was included from four faculties of teacher education in four countries: Bosnia and Herzegovina $(\mathrm{N}=150)$, Croatia $(\mathrm{N}=283)$, Slovenia $(\mathrm{N}=146)$, and Serbia $(\mathrm{N}=133)$, total $\mathrm{N}=712(\mathrm{M}=31, \mathrm{~F}=681)^{4,5}$, due to the two factors: close cooperation with these universities and geographical nearness. The average age of all students was $\mathrm{M}=21.365$ ( $\mathrm{SD}=2.708$ ), age range between 18 and 43 years, and the distribution significantly deviated from the normal $(\mathrm{K}-\mathrm{S}, \mathrm{z}=4.954, \mathrm{p}=0.001)$. Detailed information on the sub-samples with regards to each country is shown in Table 1.

Table 1

Structure of the Sample Concerning the Study Programme, Level of Study, Country, and Attending a Course on Environment/Sustainability

\begin{tabular}{|c|c|c|c|c|c|}
\hline \multirow[b]{2}{*}{$\begin{array}{l}\text { Type of study } \\
\text { programme }\end{array}$} & \multirow[b]{2}{*}{ Level of study } & \multicolumn{4}{|c|}{ Countries } \\
\hline & & $\begin{array}{c}\text { Bosnia and } \\
\text { Herzegovina } \\
(\mathrm{BIH})\end{array}$ & $\begin{array}{c}\text { Croatia } \\
\text { (HR) }\end{array}$ & $\begin{array}{l}\text { Slovenia } \\
\text { (SLO) }\end{array}$ & $\begin{array}{l}\text { Serbia } \\
\text { (SRB) }\end{array}$ \\
\hline \multirow{4}{*}{$\begin{array}{l}\text { Faculty of } \\
\text { Teacher Education }\end{array}$} & undergraduate & 52 & & 71 & 57 \\
\hline & graduate & 22 & & 10 & \\
\hline & $\begin{array}{l}\text { integrated (under- } \\
\text { graduate and graduate) }\end{array}$ & & 183 & & 16 \\
\hline & professional & 7 & & & \\
\hline \multirow{3}{*}{$\begin{array}{l}\text { Early and pre- } \\
\text { school education }\end{array}$} & undergraduate & 59 & 100 & 1 & 59 \\
\hline & graduate & 10 & & & \\
\hline & professional & & & 64 & \\
\hline \multirow[t]{2}{*}{ Attended a course } & Yes & 80 & 135 & 39 & 81 \\
\hline & $\mathrm{No}$ & 70 & 148 & 107 & 52 \\
\hline Total & & 150 & 283 & 146 & 133 \\
\hline
\end{tabular}

\section{Measuring}

In the research, a measuring instrument was used with the original title "Questionnaire on SB" (Juárez-Nájera, 2010), which was adapted and validated in the language area of the research under the name Scale of SB (Anđić and Tatalović Vorkapić, 2015).

The Scale of SB in the original (Juárez-Nájera, 2010) ${ }^{6}$ and the Croatian version (Anđić and Tatalović Vorkapić, 2015) 7 consist of four scales: Schwartz's universal human values, awareness of environmental/sustainability problems, responsibility for environmental/sustainability problems, and intra- and interpersonal intelligence for sustainability. The questionnaire also includes questions on the respondents' socio-demographic characteristics (name, level, and year of study, gender, age, and attending a course on ecology/ sustainability). In the research, we used the original questionnaire and we conducted 
only a linguistic adaptation of the questionnaire ${ }^{8}$. The Scale of Awareness of the Consequences contained nine items pertaining to the examination of awareness of the consequences of global environmental/sustainability problems such as climate change, destruction, and disappearance of tropical forests, air, water, and soil pollution, survival of plant and animal species on the individual, personal, family and national levels (Juárez-Nájera, 2010). The respondents were offered three options (1 - a very serious problem, $2-a$ somewhat serious problem; 3 - not so serious problem) to which they responded by circling the appropriate answer. Factor analysis resulted in a one-factor structure with eigenvalue of 4.54 , which explained $50.4 \%$ of the total variance. In this paper, the reliability analysis showed a satisfactory level of reliability of the Cronbach alpha coefficient $\alpha=0.847$ in the total sample and in the sub-samples of countries (BIH $\alpha=0.833$; $\mathrm{HR} \alpha=0.841$; SLO $\alpha=0.894$; SRB $\alpha=0.804)$. The Scale of Attribution of Responsibility included the following items: the examination of accepting responsibility for the current problems of environment/sustainable development on a personal and national level; responsibility of business companies for global problems such as climate change, preservation of tropical forests, toxins in the soil, air, and water, pollution of the environment, and the prevention and elimination of these environmental problems (Juárez-Nájera, 2010). The scale consisted of nine items and the respondents selected one of the answers on a scale of 1 to 5 (1-strongly disagree; 2 - partly disagree; 3 - maybe; neither agree nor disagree; 4 - partly agree; 5 - strongly agree). The factor analysis obtained one factor with eigenvalue of 4.4 , which explained $48.8 \%$ of the variance. In this paper, the level of reliability of the total sample was Cronbach $a=0.792$ and on the sub-samples of countries (BIH $\mathrm{a}=0.756 ; \mathrm{HR} \mathrm{a}=0.815 ; \mathrm{SLO} \mathrm{a}=0.813$; $\mathrm{SRB} \mathrm{a}=0.769)$.

\section{Data Collection and Data Analysis Procedures}

The research was conducted and administered in four countries. In all these countries the questionnaire was prepared in agreement with individual lecturers and during class. In this paper, the procedures of the factor analysis (exploratory factor analysis under the component model and application of oblimin rotations) were processed, and the results obtained on the scales of awareness of the consequences and the attribution of responsibility were shown. An identical number of items were held due to a possibility of comparison with the results from the original research. Students were duly informed about the application of the questionnaire and their participation in the research was voluntary, anonymous and in accordance with ethical considerations. Since the participation of all students was completely anonymous, there were no ethical problems within the process of gathering data. All the statistical analyses were performed using Statistical Package for the Social Sciences (SPSS), Version 22.

\section{Results}

Shown here are the results of the analyses carried out in the four countries: awareness of environmental/sustainability problems (Table 2 ) and responsibility for environmental/ sustainability problems (Table 3 ). 
Table 2

Descriptive Parameters and the Results of the Kruskal-Wallis Test ${ }^{9}$ of the Significance of Differences in the Awareness of Environmental/Sustainability Problems ${ }^{10}$

\begin{tabular}{ccccccc}
\hline \multirow{2}{*}{ Country } & \multicolumn{3}{c}{ Awareness } & \multicolumn{3}{c}{ Kruskal-Wallis test $\left(\chi^{2}\right)$} \\
\cline { 2 - 7 } & $\mathrm{M}(\mathrm{SD})$ & Range & $\mathrm{K}-\mathrm{S}(\mathrm{z}, \mathrm{p})^{11}$ & HR & SLO & SRB \\
\hline BIH & $1.46(0.367)$ & $1-3$ & $1556^{*}$ & $23.311^{* * *}$ & $14.315^{* * *}$ & 0.013 \\
\hline HR & $1.34(0.328)$ & $1-3$ & $2.718^{* * *}$ & & 0.281 & $15.217^{* * * *}$ \\
\hline SLO & $1.35(0.375)$ & $1-3$ & $2.148^{* * *}$ & & & $11.141^{* * *}$ \\
\hline SRB & $1.46(0.349)$ & $1-3$ & $1.703^{* *}$ & & & \\
\hline Total & $1.39(0.354)$ & $1-3$ & $3.744^{* * *}$ & & & \\
\hline
\end{tabular}

Students identified the covered environmental/sustainability problems as a very serious problem. By testing the differences with the Kruskal-Wallis test (significant deviation from normal distribution), it was determined that: Croatian $(\mathrm{M}=1.34$, $\left.\mathrm{SD}=0.328 ; \chi^{2}=23.311, \mathrm{p}=0.00\right)$ and Slovenian students $(\mathrm{M}=1.35, \mathrm{SD}=0.375)$; $\left.\chi^{2}=14.315, \mathrm{p}=0.001\right)$ expressed a significantly greater awareness than Serbian $(\mathrm{M}=1.46$, $\left.\mathrm{SD}=0.349 ; \chi^{2}=15.217, \mathrm{p}=0.001\right)$ and Bosnian students $(\mathrm{M}=1.46, \mathrm{SD}=0.367$; $\chi^{2}=11.141, \mathrm{p}=0.001$ ) (Table 2). Significant differences in the awareness were confirmed between the students from Bosnia and Herzegovina and Serbia, as well as between the students from Croatia and Slovenia.

Table 3

Descriptive Parameters and the Results of the Kruskal-Wallis Test of the Significance of Differences in the Responsibility for Environmental/Sustainability Problems

\begin{tabular}{ccccccc}
\hline \multirow{2}{*}{ Country } & \multicolumn{3}{c}{ Responsibility } & \multicolumn{3}{c}{ Kruskal-Wallis test $\left(\chi^{2}\right)$} \\
\cline { 2 - 7 } & $\mathrm{M}(\mathrm{SD})$ & Range & K-S $(\mathrm{z}, \mathrm{p})^{11}$ & HR & SLO & SRB \\
\hline BIH & $4.09(0.521)$ & $1-5$ & 0.800 & $18.301^{* * *}$ & 5.192 & 1.796 \\
\hline HR & $4.24(0.456)$ & $1-5$ & $1.863^{* *}$ & & $16.196^{* * *}$ & $15.632^{* * *}$ \\
\hline SLO & $4.04(0.518)$ & $1-5$ & 1.306 & & & $5.081^{*}$ \\
\hline SRB & $4.15(0.561)$ & $1-5$ & 1.181 & & & \\
\hline Total & $4.15(0.508)$ & $1-5$ & $2.018^{* * *}$ & & & \\
\hline
\end{tabular}

The level of students' responsibility for problems was relatively high, i.e., in terms of the scale students, on average, partially agreed with the claims in the scale. When comparing the average responses, it was noticeable that the highest level of accountability was achieved on a sample of students from Croatia $(M=4.236, S D=0.456)$, followed by the students from Serbia $(M=4.152, S D=0.561)$, Bosnia and Herzegovina $(M=4.093$, $\mathrm{SD}=0.521)$, and Slovenia $(\mathrm{M}=4.041, \mathrm{SD}=0.518)$. The Kruskal-Wallis test showed that the students from Croatia estimated their level of responsibility significantly higher than students from other countries, i.e., students from Bosnia and Herzegovina $\left(\chi^{2}=18.301\right.$, $\mathrm{p}=0.001)$, Slovenia $\left(\chi^{2}=16.196, \mathrm{p}=0.001\right)$, and Serbia $\left(\chi^{2}=15.632, \mathrm{p}=0.001\right)$, while the students from Serbia showed a significantly greater responsibility than the students from Slovenia $\left(\chi^{2}=5.081, \mathrm{p}=0.024\right)$. Other differences were not proven to be statistically significant.

Spearman's rank correlation coefficients were also calculated in the analysis of the relationship between the results of the scales of Awareness and Responsibility on a sample of students from the four faculties of teacher education and separately for the 
students from Bosnia and Herzegovina, Croatia, Slovenia, and Serbia, taking into consideration their age, study level and whether they attended a course on ecology/sustainability (Table 4). It is important to analyse age as a separate variable from the study level, since students are more/less heterogeneous by age at the same study level, due to Bologna process at faculties.

Table 4

Spearman's Rank Correlation Coefficients between the Awareness and Responsibility for Environmental/Sustainability Problems

\begin{tabular}{lcccccccccc}
\hline & \multicolumn{9}{c}{ Awareness } & \multicolumn{6}{c}{ Responsibility } \\
\hline & BIH & HRV & SLO & SRB & Total & BH & HRV & SLO & SRB & Total \\
\hline Age & -.053 & -.035 & -.075 & $-.225^{* *}$ & -.016 & .084 & $.134^{*}$ & .046 & .084 & $.098^{*}$ \\
\hline Study level & -.040 & -.051 & -.008 & -.165 & -.050 & .015 & .107 & -.012 & .095 & $.098^{*}$ \\
\hline $\begin{array}{l}\text { Attendance of a } \\
\begin{array}{l}\text { lourse on ecology/ } \\
\text { sustainability }\end{array}\end{array}$ & -.013 & .009 & -.047 & $.252^{* *}$ & .001 & -.029 & -.057 & -.002 & -.015 & -.048 \\
\hline
\end{tabular}

**p $<0.01 ; * \mathrm{p}<0.05$

Significant correlations were found only among students from Serbia. According to results, highest value of statistically significant correlations shows that senior students are more aware of problems $\left(\mathrm{r}_{\mathrm{ho}}=-.225, \mathrm{p}<0.01\right)$ as are also those students who attended a course that included contents on ecology/sustainability $\left(r_{h o}=.252, p<0.01\right)$.

With respect to the Responsibility, the Croatian subsample showed a significant positive correlation between age and responsibility $\left(\mathrm{r}_{\mathrm{ho}}=.134, \mathrm{p}<0.05\right)$. In other words, with the increase in age there appears an increase in the estimated responsibility of students for environmental/sustainability problems. This connection was also established on the entire sample $\left(\mathrm{r}_{\mathrm{ho}}=.098, \mathrm{p}<0.05\right)$. Similarly, it was established that with a higher study level, students showed significantly higher responsibility for problems $\left(\mathrm{r}_{\mathrm{ho}}=.098\right.$, $\mathrm{p}<0.05)$. This small correlation coefficient is the only significant correlation regarding the study level and age. Since it was expected to determine different relationships of age and study level with focused variables, these results confirmed the need to analyse age separately from the study level.

\section{Discussion}

The obtained results of the awareness of environmental/sustainability problems indicate significant differences among the students from the four faculties of teacher education in the four countries. In terms of awareness, Slovenian and Croatian students have evaluated problems as being very serious, with high and statistically significant values, while in the case of the Bosnian and Serbian students the high values are not statistically significant. Here, the following should be emphasised: in the present research, the authors were dealing with a very specific sample - students from four faculties of teacher education and not a representative or a random sample of all faculties of teacher education and the entire country. In the context of the obtained results, the high values of awareness can be explained by modern educational policies that could have affected the attribution of greater importance to teacher education. The results of the final UN report on the Decade of Education for Sustainable Development 2005-2014 confirm a 
significant increase in study programmes, research, and practice for the implementation of ESD in higher education institutions, especially in teacher education. The report indicates that all Member States have concluded that teacher education is of high priority in the post-period of the Decade, which should be more systematically accessed and continuously upgraded (2014, pp. 94-95). We can also offer an explanation that is based on a system of initial teacher education in these four countries, i.e., attaching importance to environmental/sustainability problems and their implementation in the programmes of teacher education, which certainly confirms the results. Filho's (2011, p. 121) analysis indicates the following. The Republic of Slovenia is at an advanced level positioned (ESD is already part of educational programmes, including initial and vocational education, both inside and outside of schools; the public awareness is promoted actively and there are a number of organisations and associations that support and continue its implementation). The Republic of Croatia is located at a high level in the implementation process (there is a progressive implementation/ involvement in part of the educational programme; there are education and training available at several levels, but they are rather limited, while public awareness is often left unnurtured). The results are also in line with the fact that Croatia was in the negotiation process for EU accession, meaning that it was compulsory to meet the requirements set out in Chapter 27 and implement those processes. Bosnia and Herzegovina and Serbia are at the initial level (they are limited to traditional approaches, the promotion of ESD is at an early stage, and there is little emphasis on public awareness). For several decades in Slovenia a systematic policy of education has been giving increasing importance to this problem, especially at the level of study programmes of teacher education. Already in 2008 and 2009, new curricula in Slovenia emphasised an even broader interdisciplinary approach to SD in preschools and elementary schools. In the study programmes for teacher education, including the faculties where the present research was conducted and whose study programmes were analysed, courses are offered that directly and indirectly deal with problems of environment and sustainability. As for the results of Responsibility obtained from the research, the differences concerning the Slovenian respondents can be with the following attitude explained. As stated earlier, Slovenia is the only country among the surveyed countries that was at the time of the research a member of the European Union, which in this case turned out to be an important factor. Strict legal provisions to protect the environment have had an impact on the Slovenian respondents' assessment in the attribution of responsibility because it is clear that they attribute their confidence in solving these problems to competent bodies rather than attributing them to personal responsibility. These results are consistent with the results of research by Kelly et al. (2004) on the understanding of the seriousness of environmental problems and the attribution of responsibility, but also with the research by Filho (2011), where Slovenia is on equal footing with a number of European countries positioned at an advanced level of implementation.

The situation is very similar with the Croatian respondents. The highest awareness is present precisely among the Croatian respondents. The explanation of these results is twofold. Firstly, at the time of this research Croatia was in the process of entering the European Union and the stricter environmental EU policy affected the fact that ecology and ESD significantly penetrated into the focus of interest of public policy and the educational policy as well. This is also evident considering the fact that the first Parliament on Education for the Environment was held in 1996, the second in 2002, and the Republic 
of Croatia was one of the signatories of the Kyoto Agreement. SD and ESD have been designated as a strategic issue for the country, a fundamental educational value, and a cross-curricular theme. The authors of the present research point out the following: respondents in the Croatian sample were all students enrolled at the Faculty of Teacher Education, University of Rijeka, and they were all female. Explanation of the result differences by gender, i.e., of the higher values, is in line with the research presented in the theoretical part of this paper. However, in the context of these results, regardless of the mostly female sample of respondents, it should be emphasised that the explanation is also based on the content of educational programmes for future teachers, similar to the Slovenian respondents.

Croatian respondents are students of the Faculty of Teacher Education in Rijeka, a faculty at which systematic pedagogical thinking and working in the field of education for the environment have been present since the early 1990s. Currently all university students of initial teacher education are attending the obligatory course "Pedagogy of SD" at the University of Rijeka. University students at other faculties, included in the present research, are attending only elective courses during their initial teacher education. The concept of SD and implementation on different levels of practice is included in the Strategy of the University of Rijeka. There is a long tradition of the School of SD aimed at university students. In this way, the resulting high values of the results in awareness, but also in responsibility, are, on the one hand, expected among the Croatian respondents, and, on the other hand, easily explainable. Previous research conducted at the University of Rijeka (Borić, Jindra, and Škugor, 2008; Rončević and Rafajac, 2012) is consistent with the results of the present research. In relation to the students' attitudes, students in their senior years of study demonstrated a greater awareness and perception of the responsibilities of all stakeholders in the promotion and implementation of ESD. Programmes for the education of elementary and preschool teachers in Serbia offer courses on environmental protection and SD only in the senior years of study. The results obtained from the respondents from Bosnia and Herzegovina, despite the fact that they are lower in comparison with other respondents, indicate high values. Analysis of these study programmes suggests that three elective courses related to the environment, sustainable development, and intercultural education are offered. The analysis has also made it clear that the results of the Croatian respondents, but also those from other countries, can be brought into connection with the study year/level of education and age. Research results confirm the connection between attending a course with a higher level of awareness among students in senior years of studies in Serbia. Therefore, with an increase in age there appears an increase in responsibility: students from senior years of study demonstrate greater responsibility for environmental problems.

This is certainly related to the fact that courses related to ESD are usually offered in the senior years of teacher education study. It is also a good indicator for the creation of future initial educational programmes for students of faculties of teacher education, and not only in Serbia but also in other countries, which suggests that such content should be offered much earlier and a more systematic access to higher education should be provided. If we observe the results of awareness and responsibility as a whole, it is clear that one does not imply the other. Besong and Holland stated as a conclusion of their own research $(2015$, p.18), "These findings clearly indicate that despite general awareness on environmental matters there is the need to mainstream climate change education in higher education curricula so as to provide learners with the knowledge, 
skills and competencies to carry out strategic planning...”. Finally, a discussion of these results simultaneously raises a few more questions: why are education and training for sustainability not significantly developed in teacher education? Why do these issues appear only in senior years of study and why are there so few courses? At the same time, it raises the question: who will ultimately create such curricula and courses, and implement the approaches in the higher education of teachers? According to Nikolic, Milutinovic, Nedanovski and Mrnjaus (2017, p. 924), "Higher education in South Eastern Europe (SEE) is currently confronted with the pressures and expectations of a variety of academic and non-academic factors in the form of low investment in education, higher pressure on the system coupled with the low capacity of public universities to absorb the increased number of students, low student scholarships and high enrolment fees and increasing absorption of students at private universities, followed by lower quality control mechanisms". Ultimately, it can be concluded that the professional development of university lecturers in this part of the European region is poorly developed and mostly still marginalised. This is not in line with the fact that there is a long history on the European soil of the existence of significant policy documents that bind European universities to implement sustainable development in higher education. Some of these universities belong to countries where the present research has been conducted. In addition, the authors of the research would like to point out that "...the seeds of a CPD attitudes and a commitment to career-long sustainable professional development should be established in teachers during pre-service and in-service training (Mohammadi and Moradi, 2017, p. 36). Such an attitude suggests that higher education institutions, which include the initial education of future teachers in sustainability, especially in this part of Europe, need not only to reinforce the implementation of sustainability content in their curricula, learning and teaching, or study programmes, but it is also necessary to strengthen and establish an institutional support (Redman, 2013) and professional development system in order to monitor and evaluate these processes (Mohammadi and Moradi, 2017).

\section{Conclusions and Implications}

In relation to the hypotheses set in the present paper, the authors can conclude that the hypothesis about the high values of awareness and responsibility in all respondents has been confirmed. The third hypothesis has been only partially confirmed and it refers to the expected correlation of responsibility and awareness and socio-demographic variables (age and previous course attendance) whereby in the majority of the countries there have been no significant correlations. Positive correlations have been obtained from respondents from Serbia and especially from Croatian respondents with respect to age and responsibility. The last hypothesis has not been confirmed because statistically significant differences in awareness and responsibility have been found among the respondents. Results of the research indicate that the greatest awareness of environmental/ sustainability problems is present among the students of the Faculty of Teacher Education in Croatia and Slovenia, among whom the authors have not found statistically significant differences compared to the results of respondents from Bosnia and Herzegovina and Serbia, among whom the authors have also not found statistically significant differences. Results of the responsibility for environmental/sustainability problems indicate the highest level present among students from Croatia and Serbia, and lower among the students 
from Bosnia and Herzegovina and Slovenia. It is clear from these results that there is a difference among the students of the faculties of teacher education and it is the result of both national education policies and levels of implementation processes into study programmes of teacher education, especially in terms of these four Faculties of Teacher Education from where the respondents come from. In this regard, the importance of highlighting the membership/process of EU accession in the countries where the research has been conducted suggests that this has proved to be an important factor in the discussion of the obtained results.

Croatian respondents have at their disposal study programmes that are most common in the content of ESD, in relation to others. With the Slovenian respondents, the situation is very similar and corresponds to the process of implementation and attribution of significance to this problem, but also to the status of Slovenia as the EU Member State. Results in relation to gender, although not specifically researched, correspond to the fact that the research has for the most part been conducted on female respondents. In terms of age, the results correspond to the fact that these courses in study programmes appear later during the senior years of study and among older respondents, i.e., on the entire sample. Among Croatian students, these results correspond to the accountability and among Serbian students - to the awareness concerning attending a course on ecology/ sustainability. Finally, attending a course on ecology/sustainability has not proven to be significant in any of the groups of students; however, by implication, the results indicate that these courses should start earlier.

Although the sample size is satisfactory, this is an appropriate and specific sample, students from the four faculties of teacher education in four countries, so the guideline for future research would be to test the findings on a random sample. The limitation of the research is the fact that students from other educational directions were not included, for example, subject teachers or members of professional development services (psychologists, special education teachers).

In relation to the hypotheses of the research, some have been confirmed while others have not been, the authors can point out that they are certainly a basis for further research. The authors can suggest further development of ESD and sustainability that will promote key elements: knowledge domains and pedagogies for the development of values, attitudes, awareness, and responsibility as personal norms and other important factors that may contribute to the construction of SB and implementation of ESD.

Future research should certainly include a larger and more representative sample that will include students from all faculties of teacher education and universities at the national level, which would be an initial step in the implementation of the results of the present research. A further step would be the possibility to apply it to faculties of teacher education and compare it with other universities so that the comparison of the results could be generalised better and set as a kind of research framework of this problem, including the policy and cross-cultural domain as an additional scientific contribution to researching this problem.

Any future research on such a foundation and the comparison of their results would certainly be more appropriate. In those contexts, future studies, from the position of the requirements of modern educational policies in which teacher education for sustainability and ESD is recognized, should be a fundamental priority in developing the concept and the levels of implementation of ESD at the global level. 
Notes:

(1) For more details, see Anđić and Tatalović Vorkapić (2015).

(2) As far as we are aware, such research has not been carried out at faculties of teacher education in the countries where we conducted our research. Similar studies have been carried out, some of which are mentioned in the discussion.

(3) The group of students implies Bosnian, Croatian, Slovenian, and Serbian university students.

(4) "Similar to the findings across Europe, elementary and compulsory schools are characterised by marked feminization of the profession, and generally there is a high level of competition for enrolment in subject and class teaching, as well as in entering the profession" (Vizek Vidović, 2005, p. 14)

(5) Percentage of female teachers in primary and secondary schools (EC, 2013, p. 70)

(6) In the original research, Juárez-Nájera (2010) applied the questionnaire to 80 respondents, students from a Mexican university, and 37 respondents from a German university.

(7) Validation and adaptation of the questionnaire were carried out on a sample of 480 students from the University of Rijeka (Croatia), whereby the adaptation included exclusively the linguistic adaptation, and the scales were used in their original form. In the validation of the questionnaire, the ratio of respondents by sex was $40 \%$ male and $60 \%$ female respondents (Anđić and Tatalović Vorkapić, 2015).

(8) The same linguistic/speech area.

(9) The Kruskall-Wallis test was used as a non-parametric test. $\chi^{2}$ presents a measurement unit for test and significance of differences.

(10) Significance results of test are bolded.

(11) K-S ( $z, p)$ presents Komogorov-Smirnov test, test results with $z$ value and $p$ value as an indicator of using non-parametic statistics, ${ }^{*} \mathrm{p}=.001 ; * \mathrm{p}=0.005 ; \mathrm{p}^{* * *}=0.05$.

\section{References}

Anđić, D., \& Tatalović Vorkapić, S. (2014). Kako mjeriti održivo ponašanje? Adaptacija i validacija Upitnika o održivom ponašanju. (How to measure SB? Adaptation and validation of the questionnaire on SB). Revija za sociologiju, 45(1), 69-97. doi: 10.5613/rzs.45.1.3

Anđić, D., \& Tatalović Vorkapić, S. (2015). Interdisciplinary approaches to sustainable development in higher education: A case study from Croatia. In K. D. Thomas \& Muga, E. H. (Eds.), Handbook of Research on Pedagogical Innovations for Sustainable Development (pp. 67-115). Hershey: IGI Global. doi: 10.4018/978-1-46665856-1.ch005

Besong, F., \& Holland, C. (2015). The dispositions, abilities and behaviours (DAB) framework for profiling learners' sustainability competencies in higher education. Journal of Teacher Education for Sustainability, 17(1), 5-22. Retrieved 26 October 2017, from https:/www.degruyter.com/downloadpdf/j/jtes.2015.17.issue-1/jtes2015-0001/jtes-2015-0001.pdf

Beringer, A., Malone, L., \& Wright, T. (2006). Sustainability in higher education. International Journal of Sustainability in Higher Education, 9(1), 48-66.

Bertschy, F., Künzli, C., \& Lehmann, M. (2013). Teachers' competencies for the implementation of educational offers in the field of education for sustainable development. Sustainability, 5, 5067-5080. doi: 10.3390/su5125067 
Blamey, R. (1998). The activation of environmental norms: extending Schwartz's model. Environment and Behaviour, 30, 676-708.

Borić, E., Jindra, R., \& Škugor, A. (2008). Razumijevanje i primjena sadržaja cjeloživotnog učenja za održivi razvoj. (Understanding and application of content of lifelong learning for sustainable development). Odgojne znanosti, 10(2), 315-327.

Boyatzis, R. E., \& Sala, F. (2004). Assessing emotional intelligence competencies. In G. Geher (Ed.), The measurement of emotional intelligence (pp. 147-180). Hauppauge, NY: Nova Science Publishers.

Cebrián, G., \& Junyent, M. (2015). Competencies in education for sustainable development: Exploring the student teachers' views. Sustainability, 7(3), 2768-2786. Retrieved 10 September 2016, from http://www.mdpi.com/2071-1050/7/3/2768. DOI: $10.3390 /$ su7032768

Davey, I. (2012). Roles of awareness and intention in determining levels of environmentally positive action: A review of studies. JOAAG, 7(1), 23-42.

De Groot, J. I. M., \& Steg, L. (2009). Mean or green? Values, morality and environmental significant behaviour. Conservation Letters, 2, 61-66. doi: 10.1111/j.1755-263X. 2009.00048.x

Dietz, T., Stern, P. C., \& Guagnano, G. A. (1995). The new ecological paradigm in social-psychological context. Environment and Behaviour, 27, 723-743. doi: $10.1177 / 0013916595276001$

Dietz, T., Stern, P. C., \& Guagnano, G. A. (1998). Social structural and social psychological bases of environmental concern. Environment and Behaviour, 30, 450-471. doi: 10.1177/001391659803000402

Dunlap, R. E., Van Liere, K. D., Mertig, A. G., \& Jones, R. E. (2000). Measuring endorsement of the new ecological paradigm: A revised NEP scale. Journal of Social Problems, 56(3), 425-442.

Ebreo, A., Vinig, J., \& Cristancho, S. (2002-2003). Responsibility for environmental problems and the consequences of waste reduction: A test of the norm-activation model. J. Environmental systems, 29(3), 219-244. Baywood Publishing Co., Inc.

European Commission. (2013). Teacher education and training in the Western Balkans. Final synthesis report. ISBN 978-92-79-32657-8. doi: 10.2766/62097. Retrieved 10 September 2016, from http://ec.europa.eu/dgs/education_culture/repository/ education/international-cooperation/documents/western-balkans/teacher-trainingreport_en.pdf

Heberlein, T. A. (1972). The land ethic realized: Some social psychological explanations for changing environmental attitudes. Journal of Social Problems, 28, 79-87. doi: 10.1111/j.1540-4560.1972.tb00047.x

Huckle, J. (2006). Education for sustainable development: A briefing paper for the teacher training resource bank (TDA). Updated edition 10/06. Retrieved 15 October 2012, from http://john.huckle.org.uk/publications_downloads.jsp

Filho, W. L. (2011). An overview of ESD in European Countries: What is the role of national governments? Global Environmental Research, 14(2), 119-124.

Juárez-Nájera, M. (2010). Sustainability in higher education. An explorative approach on SB in two universities. Doctoral Thesis, Erasmus University Rotterdam.

Kelly, M., Kennedy, F., Faughnan, P., \& Tovey, H. (2004). Environmental attitudes and behaviours: Ireland in comparative European perspective. Third Report of 
National Survey Data. Social Science Research Centre. Environmental RTDI Programme 2000-2006, Grant no. 2001-MS/SE1-M1.

Krajhanzl, J. (2010). Environmental and proenvironmental behaviour. In E. Rehulka (Ed.), Health education: International experiences (pp. 251-274). Brno: Masarykova univerzita. Retrieved 5 September 2014, from http://www.ped.muni.cz/z21/knihy/ 2010/35/35/texty/sh21_2010_english.pdf

Mader, M., Tilbury, D., Dlouha, J., Benayas, J., Michelsen, G., Mader, C., \& Alba, D. (2014). State of the art report: Mapping opportunities for developing Education for Sustainable Development competences in the UE4SD partner countries. University Educators for Sustainable Development. Retrieved 5 October 2017, from http://platform.ue4sd.eu/downloads/UE4SD_State_of_the_Art_Report.pdf

Milfont, T. L., Sibley, C. G., \& Duckitt, J. (2010). Testing the moderating role of the components of norm activation on the relationship between values and environmental behaviour. Journal of Cross-Cultural Psychology, 41-124. doi: 10.1177/ 0022022109350506

Nikolic, V., Milutinovic, S., Nedanovski, P., \& Mrnjaus, K. (2017). ESD professional development of university educators in Serbia, Croatia and Macedonia: A comparative analysis. International Journal of Sustainability in Higher Education, 18(6), 923938, Retrieved 5 October 2017, from https://doi.org/10.1108/IJSHE-02-2016-0036

Redman, E. (2013). Opportunities and challenges for integrating sustainability education into k-12 schools: Case study phoenix, AZ. Journal of Teacher Education for Sustainability, 15(2), 5-24. doi: 10.2478/jtes-2013-0008

Rončević, N., \& Rafajac, B. (2012). Održivi razvoj - Izazov za sveučilište? Filozofski fakultet u Rijeci. Sveučilište u Rijeci.

Ryan, A., \& Spash, C. L. (2008). Measuring awareness of environmental consequences: Two scales and two interpretations. Socio-Economics and Environment in Discussion. Csiro Working Paper Series no. 2008-2010. Sustainable Ecosystems, 2008. ISBN 1834-5638.

Schwartz, S. H. (1970). Moral decision making and behaviour. In J. Macaulay and L. Berkowitz (Eds.), Altruism and helping behaviour (pp. 127-141). New York: Academic Press.

Schwartz, S. H. (1977). Normative influences on altruism. In L. Berkowitz (Ed.), Advances in experimental social psychology, 10 (pp. 221-279). New York: Academic Press.

Schultz, P. W., Gouveia, V. V., Cameron, L. D., Tankha, G., Schmuck, P., \& Franek, M. (2005). Values and their relationship to environmental concern and conservation behaviour. Journal of Cross-Cultural Psychology, 36, 457-475.

Scott, D., \& Willits, F. K. Z. (1994). Environmental attitudes and behaviour: A Pennsylvania survey. Environment \& Behaviour, 26, 239-260.

Steg, L., \& De Groot, J. (2010). Explaining prosocial intentions: Testing causal relationships in the norm activation model. British Journal of Social Psychology, 49, 725743. The British Psychological Society, DOI: 10.1348/014466609X477745

Stern, P. C., Dietz, T., Abel, T., Guagnano, G. A., \& Kaloff, L. (1999). A value-beliefnorm theory of support for social movements: The case of environmentalism. Research in Human Ecology, 6, 81-97.

Stern, P. C. (2000). Toward a coherent theory on environmentally significant behaviour. Journal of Social Problems, 56, 407-424. doi: 10.1111/0022-4537.00175 
UNESCO. (2005). Guidelines and recommendations for reorienting teacher education to address sustainability. Education for sustainable development in action. Technical Paper no. 2. Paris: UNESCO. Retrieved 31 January 2005, from http://unesdoc. unesco.org/images/0014/001433/143370e.pdf

UNESCO. (2014). Shaping the Future We Want, UN Decade of Education for Sustainable Development (2005-2014). Final Report. The United Nations Educational, Scientific and Cultural Organization. ISBN 978-92-3-100053-9.

Van Liere, K. D., \& Dunlap, R. E. (1978). Moral norms and environmental behaviour: An application of Schwartz's norm activation model to yard burning. Journal of Applied Social Psychology, 8, 174-188.

Zelezny, C. Z., Chua, P., \& Aldrich, C. $(2000,2002)$. New ways of thinking about environmentalism: Elaborating on gender differences in environmentalism. Journal of Social Problem, 56(3), 443-457. doi: 10.1111/0022-4537.00177

Vicente-Molina, M. A., Fernandez-Sainz, A., \& Izagirre-Olaizola, J. (2013). Environmental knowledge and other variables affecting pro-environmental behaviour: Comparison of university students from emerging and advanced countries. Journal of Cleaner Production. doi: 10.1016/j.jclepro.2013.05.015

Vizek Vidović, V. (Ed.) (2005). Teacher education in Europe from the perspective of lifelong learning (pp. 15-60). Zagreb: Institut za društvena istraživanja u Zagrebu.

Correspondence concerning this paper should be addressed to Dunja Anđić, PhD, Assistant Professor, Faculty of Teacher Education, University of Rijeka, University Avenue 6/Campus, 51000 Rijeka, Republic of Croatia. Email: dunjaklana.dk@gmail.com 